\title{
Religious Education in Uzbekistan under Soviet Imperialism. A Secular Based Approach
}

\author{
Riyaz Ahmad Sheikh* \\ Research Scholar, Centre of Central Asian Studies, University of Kashmir, Srinagar, \\ India
}

\begin{abstract}
It is imperative to identify and analyze the educational policies, embarked in Soviet Central Asia. This paper investigates the seven decades Communist rule in Muslim oriented Central Asia with a special focus to Islamic education policies and approaches. The Communist party serves as a seedbed of power not only in economics and politics but also in the realm of ideology and education. The interrogation and persecution on Religious education institutions, its carriers and scholars, Ulamas and believers clearly depicts the atheistic religious policy of soviets. Atheistic propaganda was intensified in the early 1920's and 1930's arbitrary arrests and execution took place to eliminate Muslim leaders who refused to cooperate with the authorities. All Islamic schools (Maktabas and Madrassas) were closed and religious literature was confiscated. Inspite the approach of "drying them out" Islamic education survived in hujra (monastic cell) system of education.
\end{abstract}

Key Words; Soviet, Religion, Secular, Education, Hujra, Maktabas and Madrassas.

\section{Introduction}

Transoxiana, known in the Arabic and Persian sources as Mawara- al- Nahr, ${ }^{1}$ is the ancient name used for the portion of Central Asia corresponding modern-day Uzbekistan, Tajikistan, South Kyrgyzstan, and southwest Kazakhstan. The area had been known to the Greeks as Transoxiana (land beyond the river Oxus) and to the Iranians as Turan, (the land of the Tur) a term used in the Persian national epic Shah-nama. Geographically it is the area between the Anu Darya and Syr Darya. Central Asia ${ }^{2}$ in the modern geographical designation covering an area of considerable political, ethnic and linguistic diversity, marked by a distinctive cultural synthesis rooted in the meeting of the civilization of inner Asia, with that of Middle Asia and the Islamic World. ${ }^{3}$

From the times of immemorial, central Asia had close ties with different ethnic groups. The Sakes, the Parathares, the Huns, the Arabs, the Turks, and the Mongols had laid tremendous

\footnotetext{
1 For more details see Erkin Alptekin, "Relations between Eastern and Western Turkistan."Radio Liberty Research Bulletin, 51, December 21, 1988.

2 The term Central Asia is a Soviet invention and includes only the four former Soviet Asian Republics. Arab definition of the area is the land on the other side of the River (Mawara- alNahr).

3 Elizabeth. E. Bacon. "Central Asia under Russian Rule; A Study in Cultural Change". Cornell University Press, 1996. P.5
}

DOI : $10.5121 /$ ije.2015.3304 
impact on the world history in general and Central Asian history, cultural, Language, Education etc in particular.

The call of Islam reached central Asia during the mid of $7^{\text {th }}$ century, through three distinctive ways, via the Arab armies (led by Qutayba Ibn Muslim), Scholaristic way and traders' way. The Islamization of the region was accomplished quite rapidly. Within some 50 years, Transoxiana had been incorporated politically, culturally and economically incorporated into the Islamic Caliphate. The roots of Islamic faith were strengthened during the Karakhanid and Seljuk empires. Islam developed deeper historical roots in the non-nomadic Tajik and Uzbek populations than among the nomadic Kyrgyz, Turkmen, and Kazakh tribes. ${ }^{4}$ Islam laid its dramatic influence on every aspect of human life. Islam gave fillip to the knowledge and widened its scope and disseminated the knowledge to the outer world. Education, science and technology got a new orientation in the region. During the Muslim era research in the field of Astronomy, Mathematics, medicine, Pharmacology and Geography reached its zenith. Great legendaries like Abu Musa al Khawazimi, Al -Farabi, Ibn-Sina, and Al -Buruni, cities like Bukhara, Marv, Samarqand and Farghana were great centres of Islamic learning. Ibn -Sina's "Al Qanun fi Tibb" became text-book in Western universities for a quite longer time. During the Muslim rule, scholarship made great strides and there was host of scholars existed in every branch of knowledge, as evidenced by works of Tarikh-i-Bukhara, Mujumul-Buldan (Marvels of the Land), Shah-nama, Garshasp-nama (Epic of Garshasp), Hudud al Alam. In mathematics, Ahmad b Abd Allah Al- Marwazi (popularly known as Al Habash al -Khasib.d.870), Abu Mashar Balkhi(d.886) and Abu Ahmad al Fergana, an astronomer and mathematician wrote Usul ilm al Nujum(Principles of Astronomy).The period produced two great polymaths Ibn - Sina and Abu Rahman al Buruni from Khawazam the scholar of central Asia who emerged during the Muslim era have left an indelible mark on the world and certainly during the period from the $7^{\text {th }}$ century to the end of the fifteenth century. This is marked still age of achievement in the annals of world history. ${ }^{5}$

In the eighteenth century Tsarist penetration started in the region, the main regional entities in the southern tier were the Khanates of Bukhara, Khiva and Kokand; in the North, there were three Kazak tribal confederations or Hordes (known respectively as the Big, the little and the Middle Horde). The Tsarist annexation of Central Asia took place with relatively little local resistance. The Kazaks were the first to come under Russian rule. This was a creeping process which took over a century to complete, lasting from the mid-eighteenth century to the mid-nineteenth century. The conquest of the Khanates began with the fall of Tashkent in 1865. Bukhara and Khiva became protectorates in 1868 and 1873 respectively; Kokand was fully integrated into the Russian Empire in 1876. Transcaspia (modern Turkmenistan) was conquered in the 1880s.

\section{Russian Revolution and Jadidism in Central Asia}

The beginning of the Bolshevik revolution introduced a new era in the Central Asian region across all sectors of the society including education.. On the eve of the Bolshevik Revolution, three major and distinct formal educational authorities functioned in Central Asia; the traditional Islamic education system, the Russian education system, and Jadidists education system.

\footnotetext{
4 Ahmed Rashid, "The New Struggle in Central Asia: A Primer for the Baffled," World Policy Journal 17, no.4 (2000/2001): 33.

5 Asimov M.S. (1997). History of Civilization of Central Asia. Vol. IV. Part. IV. UNECO. London, p.39
} 
Jadidism was originated by the national-progressive intellectuals of the region. The term in Arabic means "New" and came into existence from the concept of "Usual-i-jadid (a new method).

Abd Akkah Avlani (1970-1934), was convinced that the Traditional Islamic schools neither by their character nor by their programmes could meet the demands of modern education. ${ }^{6}$

Various proponents of reform movements such as Mahmudhodzha Behbudi (1875-1919), Munavrar Abdulrashidhanov (1878-1931), Abdullah Avlovi (1878-1934) and Miryakubn Dawlat (1885-1935) actively participated in the socio-political and cultural life of the region. They normally referred to themselves as "taraqqipararvarlar (progressive)". They argued that their approach would bring rigors to the religious educational institutions by introducing new methods, mastery of materials and systematic Arabic language instruction. These techniques, they advocated would also bring about broad ranges of courses including Secular subjects in a new kind of Madrassas to be called Muhandasalik madrassalar or technical Madrassas ${ }^{7}$. Accordingly a number of new Jadidi Schools in Tashkent reached 24 in the year of 1917, 5 schools in the Samarqand oblast, 39 in the Syr-Darya oblast (including the environs of Tashkent) and 30 schools in the Fergana oblast. Thus the total number of new method Maktabas in Uzbekistan came to 90 schools approximately. ${ }^{8}$

Soviets initially used the jaddidler reformers with two folded aims one, to transform the education system into wholly secular, second to use them for their own purpose. The main attempt of the jadidhs was to develop an educational model that would merge religious and secular education to a new educational institution. But quickly the movement was suppressed. ${ }^{9}$ Because the soviets saw it a threat that it would emerge into a Pan-Turkism and Pan-Islamism in the soviet occupied Central Asia.

However during the Second World War a kind of Jadidi concept re-emerged. Because the Soviets themselves began to establish their own Islamic Educational institutions under a new Spiritual Directorate (SADUM)

\section{Islamic Education under Soviet Surveillance}

Soviet educational policies and strategies in central Asia has been the subject-matter of number of research studies. Numerous hypotheses have been put forth by various researchers, regarding the education set ups in general and Religious education in particular. This is undeniable fact that the research during the Soviet regime remained underdeveloped and unripe due to the political and ideological bias. The majority of researchers find the religious policies of the Soviets repressive, and this evaluation is more or less correct. ${ }^{10}$ On the eve of Russian revolution in 1917, the native population of central Asia could choose between three types of schools

\footnotetext{
${ }^{6}$ Michael Kemper, R. M. (Ed.). (2009). Islamic Education in the Soviet Unionand its Successor State. London: New York: Routledge. P.228

7 Martha Bill Olcot, "Islam in Uzbekistan, Religious education and state ideology". P.4

8 Michael Kemper, R. M. (Ed.). (2009). Islamic Education in the Soviet Unionand its Successor State. London: New York: Routledge. P.228

9 Ibid, p.223

10 Shoshana Keller, To Moscow, Not Mecca: The Soviet Campaign Against Islam in Central Asia, 1917-1941 (Westport, CT: Praeger, 2001); Alexandre Bennigsen and Marie Broxup, The Islamic Threat to the Soviet State (New York: St. Martin's Press, 1983); Alexandre Bennigsen and S. Enders Wimbush, Mystics and Commissars: Sufism in the Soviet Union (Berkeley: University of California Press, 1985).
} 
Islamic schools (Maktabas and Madrassas), (b) Jadidi schools (Based on the new teaching methods that combined religious and Secular elements) and (c) Secular-Russian Native schools. Soviets had introduced additional educational policies upon which their system could built and through which their system could operates such as (a) free education at all levels. b) Instruction in the native language. C) Co-education at all levels and in all types of schools. d), a uniform course of study. According to the data provided by Ostroumov (1913), in Turkestan there were 7,290 Maktabas (with 70,864 students) and 376 madrasas (with 9,637). Turkestan, during Soviet reign sporadic attacks has been mounted against the Islamic educational institutions and the Soviets had changed the religious thinking of the people through communism although Millennium old customs had remained like marriage, burials and customs like circumcision ${ }^{11}$. The soviet government planned to establish only one type of schools, namely the Secular Soviet Schools. It intended not only to reform but to destroy the system of traditional Islamic education. The Soviet educational policies were based on the policy of Socialism and Communism which were based on a Marxist-Lenin approach. Lenin wrote, "Our object in the field of schools is the same struggle for the bourgeoisie, we openly declared that a school outside life, outside politics is a lie and hypocrisy." ${ }^{22}$ The purpose of the education is the training of educated, thoroughly developed, active builders of a Communist society. ${ }^{13}$

In the mid of the 1920's the soviet government ran only $1 / 3$ of all primary schools in Uzbekistan. Whilst the remaining $2 / 3$ were still based on religious school systems. The number of Islamic Maktabas even increased. (Table 1)

Islamic schools according to administrative district in Uzbekistan in 1920's

\begin{tabular}{|l|c|c|}
\hline $\begin{array}{l}\text { Okrug(Administrative } \\
\text { districts) }\end{array}$ & $\begin{array}{l}\text { Number of old -method } \\
\text { schools }\end{array}$ & Number of pupils \\
\hline Tashkent & 55 & 858 \\
\hline Samarqand & 342 & 4,406 \\
\hline Fergana & 79 & 1,693 \\
\hline Andizhan & 427 & 8,692 \\
\hline Bukhara & 148 & 1972 \\
\hline Zeravshan & 105 & 1,189 \\
\hline Khodzhent & 38 & 693 \\
\hline Surkhandaria & 49 & 490 \\
\hline Kashkadaria & 119 & 1,190 \\
\hline
\end{tabular}

\section{Source; Statistical information of the Uzbek Commissariat of Education}

Despite the years of anti-Islamic propaganda (1921-1928) and despite the massive persecution of Ulama, in Turkestan which occurred in the three of repression (1927, 1937-1938 and 1949) Soviet repression against Islamic education was more from 1920 to 1985, the situation and status of Islamic religious institutions deteriorated markedly. The period had a disastrous impact on the system of Islamic education. The majority of religious schools were shut down and many important Islamic scholars were persecuted. To eliminate the Islamic schools, soviets deprived them from financial foundation although various Islamic schools could be maintained through

${ }^{11}$ Svat Soucek, A History of inner Asia, Cambridge 2000,P.26

12 V.I.Lenin collected works, Moscow, 1929. Vol.37 P.77

13 How Russia Does it(London), times educational supplement, November 29,1957.P.1520 
Waqf $^{14}$ and voluntary donations (Ihsan, Kharat, Sadqaat, and Nazr). Waqf property was legal in the Uzbek Soviet Socialist Republic from 1923 to 1926. The sixth plenum of the Uzbekistan Communist Party (13-15 June 1927) adopted a resolution which called for various measures to weaken the Spiritual Directorate, to stop the reform process in Islamic schools, to eliminate Islamic schools in general by depriving them of their financial foundation, and finally to ban Islamic schools as well as ban mullahs from teaching. On 8 April 1929, the Russian VTsIK presidency passed a new law on religious organisations In accordance with the law; the government took up a general course towards the complete destruction of Islamic schools. In 1918, a decree was announced "on the separation of Church and State and of schools and Church". In November 1928, the sixth session of the UzSSR adopted the decree "On the liquidation of old method schools and Madrassas"

Islamic schooling remained the most important factor of continuity in education the Soviet reign In 1927, 199 Maktabas existed in the Kokand Okrug, whilst in the Nur-Ata reign and the Samarkand Okrug the number of Maktabas steadily increased by ten Maktabas. Also in the city of Andizhan there were still slightly more religious than soviets schools in the academic year $1926 / 1927 .^{15}$

The era Nikita Khrushchev (1953-1964), brought a new wave of persecution and his approach supposedly pushed the country on its way towards Communism. In 1961, the new programme of the communist party promulgated that the country had entered a new and extensive stage of building communism. The Baraq-khan madrasa was closed in 1961.

\section{Hujra system of Education}

The term Hujra (also doira) means circle and often refers to the institution in which religious education is offered and continues to take place. The hujra were direct a response to the atheistic policies of the soviets and the mass persecution of Ulamas and shunt downs of Islamic schools. Nevertheless after the liquidation of confessional education between 1920s, and 1930s religious education managed was continued underground called Hujra. ${ }^{16}$ The form and content of education in the hujra system remained traditional and had a conservative character. ${ }^{17}$ They trained experts in the religious(Ulama) of a relatively high level in comparison with official educational institutions of S.A.D.UM.(1943-992) The Stalin () years were the grimmest for religious education, and virtually none of the surviving clerics was willing to take on pupils unit conditions eased somewhat after World War II. The religious education that continued was

${ }^{14}$ Waqf (an Arabic word) means "Pious foundation". It also means property set aside for religious purposes". Waqf revenues provided salaries for imams, mudarris and mullahs, and so made existence possible for primary and secondary schools (Maktabas and Madrassas), mosques, shrines and Sufi convents, thus serving to reinforce Islamic religious authority. Moreover, charitable endowments funded important welfare institutes such as orphanages.

15 Michael Kemper, R. M. (Ed.). (2009). Islamic Education in the Soviet Unionand its Successor State. London: New York: Routledge. P.238

16 The dictionary definition of hujra is "cell" or "chamber". This network was the continuation of traditional forms for Islamic education(Maktabas, Madrassas and Qari-khan)in the Soviet period it could only survive on the territory of the former Turkestan Governor General ship and especially in the Farghana valley, due to its ability to accommodated Russian forms of government and control

17 B.M .Babadzhanov, A. K. Muminov and M.B.Olcott, "Mukhamadzhan Khindustani(18921989) Religiznaia sreda ego epokhi.(2004) PP.43-59 
carried out in families in what was termed qori pochcho hujralari or hujra qori-pochcho. ${ }^{18}$ In 1956, Abdurahmonjon established his own hujra, in which students were offered the studies of the rituals in silent Ziqr-Khafi: psycho-physical concentration-tarweed prayers as well as studies of mystical poetry, including works of Jalaldin Rumi and Bedilya ( $17^{\text {th }}$ century poet). Rahmatullaalloma, established a hujra in 1978, where students were taught Arabic, the Quran, Hadith and the basic of fiqh (Islamic jurisprudence). The curriculum also includes essays of Taymiya, Maullana Maududi and Tafsir (commentary of Quran) of Syeed Qutb (FI Zalali Quran). The most famous of these hujras are. Nordirhon-domla from Tashkent, established an important hujra (existence from 1962 to mid 1970's). Hazrat Baba Muhammad ran an important hujra in Surkhandaria. Qozi -Domulla (Abdurasid-domulla) ran an influential hujra in Dushanbe. Salim-Hojji Khujandi (b.1890, d.1983) ran an important hujra in Bekabad.

During the persecution of Soviet rule, the hujra system of education allowed the Muslims of central Asia to maintain their religious educational identity and to meet their obligation by the laws of Shariah and transmit their knowledge of Islam and its laws ad to be engaged in Islamic missionary work. It represented the sufficient theological vitality to keep Muslim identity alive in the region. Despite the illegal status of many theologians, Islamic learning centres continued to have a special status in society and the respect of their communities.

\section{Islamic Education from Brezhnev to Gorbachev.}

During World War II (1939-1945), legalization of Islamic educational institutions took place in Oder to gain the loyalty of Muslims. Between 1943 and 1944, Muslim conferences held in Baku, Tashkent and Buinaksk elected their spiritual directorate in Azerbaijan, Uzbekistan and Dagestan. ${ }^{19}$ "Perestroika" (restructuring) and "glasnost" (openness) were Mikhail Gorbachev's watchwords for the renovation of the Soviet body politic and society that he pursued as general secretary of the Communist Party from 1985 until 1991.Perestroika and glasnost marked the beginning of liberalization also between religious communities and the soviet state. On 14 June 1991, the soviet Republic of Uzbekistan passed the Religious act on the freedom of conscience and religious organization. The Uzbek Religions act provided the following innovations "citizens may receive religious education and can choose the language of their religious instruction. Religious organisations have the right to establish educational institutions and leaning groups for adults' and children in accordance with the organisation's standing rules....." According to the same act "Religious organizations are allowed to send citizens abroad to foreign institutions of religious learning in order to embark upon advanced studies or to exchange experiences....vice versa."

\section{Consequences of Soviet religious educational policies}

Islamic educational institutions were deeply rooted in local religious practice, social traditions and family ties and this embeddedness guaranteed their vitality. In contrast, the soviet educational system was pushed backward by numerous administrative decrees and orders. The soviets were not interested in the reform of Islamic Maktabas, and Madrassas rather they wanted all schools to be not only secular, but also strictly atheist. The costs and benefits of soviet educational policy varied over time. From the 1920,s to the World War I the period was more disastrous, during which Islamic schools were completely shut down. Immediately after the war, SADUM was established. The Autonomous Spiritual Directorate of Muslim in central Asia and Kazakhstan

18 A qori pochcho is a relative who is able to read the Quran. This instruction was generally restricted to learning some basic prayers and some ayyat from the Quran, normally the first sura, the last ayyat from ayyat-ul-kursi(Quran 2;251), and some prayers of personal supplication (Dua)

19 Y. Ro'i, Islam in the Soviet Union: From the second World war to Gorbachev, London, 2000. 
(SADUM) was founded on the 31 July 1943 in Tashkent. Two Madrassas were open under the guidance of SADUM. Early in the establishment of soviet power it was decided to separate the school from church. This educational policy decision meant that any religious influence would formally cease and that scientific-atheistic thoughts would supplant religion. The anti-religious indoctrination expressed in militant atheistic teaching and harassment of believers. Islamic educational institutions in the central Asia under the rule of soviets faced a great disastrous, the persecution of soviets against the Islamic educational institutions (Maktabas and Madrassas) Clerics, scholars. Religious literature was publically banned.

\section{References}

[1] Akiner, Shrine (1986). .Islamic People of the Soviet Union, London.

[2] Ann, - Jo, Gross. (1992). Muslim in Centre Asia: Expression of Identity and Change. Duke University

[3] Donarld. R. Little, Jr. "The policy-Making process in the soviet education system." Ann Arbor Michigan, University Microflims. 1966

[4] E.P. Tonkonogaja, "Illiteracy Education in the Soviet Union," Literacy Discussion, Vol. 7, No. 1 (1976)

[5] Hefner, R.W. 2007. The culture, politics and future of Muslim education. In Schooling Islam: The Culture and Politics of Modern Muslim Education, ed. R.W. Hefner and M.Q. Zaman, Princeton: Princeton University Press.

[6] Jaan Pennar, Ivan Ivanovich Bakalo, George. Z. F. Bereday. (1971). Modernization and Diversity in Soviet Education. Praeger Publisher, UK.

[7] Kemper, M. 2009. The Soviet discourse on the origin and class character of Islam, 1923-1933. Welt des Islam 49:1-48.

[8] Michael Kemper, R. M. (Ed.). (2009). Islamic Education in the Soviet Unionand its Successor State. London: New York: Routledge.

[9] Nicholas Dewitt, "Strategic problems of Educational policy in the Soviet Union and the united states" comparative education review 7.june 1963

[10] Wiiiam H.E.Johson, "Russia’s Educational heritage” Pittsburgh Pennsylvania. Carragic press 1950

\section{Journals}

[1] Encausse D \& Carrere H. (1963). The Peoples of Central Asia: Cultural Development. Central Asian Survey. Vol. II. No. 2. London.

[2] Kendirbaeve, Gulnar. (1999). we are Children of Alash. Central Asian Survey, Vol. 18. No. 1. London.

[3] Panchi, F. G. (1975). Teachers' education in USSR Historical developments and current trends. Soviet Education. Vol. XIX. No. 9-10. July-Aug. Moscow.

[4] Szekel, Beah Beatrice (1978). The Development of the Soviet School in Nationality Districts. Soviet Education, vol. XX. No.3, New York. 